\title{
Effectiveness of ginger and cinnamon compresses on pain in elderly with osteoarthritis
}

\author{
Nur Fitriani ${ }^{1}$, Supriyadi ${ }^{2}$ \\ ${ }^{1,2}$ Department of Health, Muhammadiyah University of Purwokerto, Indonesia
}

\begin{tabular}{l} 
ARTICLE INFO \\
Article history: \\
Received: August 9, 2020 \\
Revised: August 20, 2020 \\
Accepted: August 30, 2020 \\
\hline $\begin{array}{l}\text { Keywords: } \\
\text { ginger compress, cinnamon } \\
\text { compress, pain, osteoarthritis, } \\
\text { elderly }\end{array}$
\end{tabular}

Corresponding Author:

Supriyadi,

Department of Health, Muhammadiyah University of Purwokerto,

Soepardjo Rustam Street KM. 7, Banyumas, Indonesia

Email: prisandi31@gmail.com

\begin{abstract}
Osteoarthritis (OA) was one of the most common chronic diseases and a major cause of pain and disability that decreased health status. This disease caused pain and disability in patients which disturbed daily activities. Warm compress is one of the non-pharmacological therapies used to reduce pain. Warm compress therapy is applied at the sub-acute and chronic stage of osteoarthritis to reduce pain, compression and pain in the joints. Warm compresses can be combined by adding ginger and cinnamon. The aim of the reaesarh to understand the effectiveness of ginger and cinnamon compresses on lowering pain in the elderly with osteoarthritis in the orphanage of Sudagaran. This research was quasi-experimental design with two pretest-posttest design groups was used in this study. The samples were collected by using a random sampling technique with a total of 15 respondents getting ginger compress and 15 respondents getting cinnamon compress which was in accordance with the inclusion and exclusion criteria. The data were analyzed by using univariate and bivariate with Mann Whitney U Test. The results of the Mann Withney U Test on the second post-therapy obtained the difference in the value of ginger compresses with $\mathrm{p}=0.417$ and the difference in comfort value of cinnamon compresses with $\mathrm{p}=0.127$. After calculating the size effect, the ginger size effect was 0.924 while the cinnamon size effect was 0.790 . The use of ginger compresses is more effective than cinnamon compresses in lowering pain in the elderly with osteoarthritis in the Community Health Center of Sudagaran.
\end{abstract}

This work is licensed under a Creative Commons Attribution 4.0 International License.

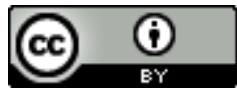

\section{INTRODUCTION}

Osteoarthritis (OA) is one of the most common chronic diseases and the main cause of pain and disability that reduces health status. The prevalence of joint disease in Indonesia reaches 34.4 million people with a disease ratio of $15.5 \%$ in men and $12.7 \%$ in women, there are $5 \%$ at the age $<40$ years, $30 \%$ at the age 40-60 years, and 65\% at the age> 60 years. [1] According to Riskesdas (basic health research) (2013 in Central Java, the prevalence of osteoarthritis sufferers was 16.7\%, [2] increasing in 2015 by $67.2 \%$. [3] Osteoarthritis is a joint disorder caused by lack of synovial fluid. It occurs when the end of the bones rub together emulating teary pain. One of the pain reliever non-pharmacological therapies is the use of warm compress. Warm compress therapy is performed at the sub-acute and chronic stage of osteoarthritis to reduce pain, increase joint flexibility, reduce pressure (compression) and pain in joints, relax muscles, and flex connective tissue (tendon ligament extensibility).

The effectiveness of warm compresses increases blood flow to get analgesic effects and soothe muscles so that the inflammatory process is reduced. Ginger compress can be combined with the addition of Ginger and Cinnamon. Ginger has the spicy, bitter, and aromatic properties of oleoresins such as zingeron, gingerol and shogaol. Oleoresin has strong anti-inflammatory and antioxidant potential. Ginger compress reduces joint pain at the transduction stage, where at this stage ginger contains gingerol which contains cyclooxygenase 
which can inhibit the formation of prostaglandins as a pain mediator, resulting in decreased joint pain. So that ginger can be used as an alternative non-pharmacological treatment to reduce pain.

Research shows that ginger compress affects the osteoarthritis pain scale in the elderly. [4] Based on research it shows that there is an effect of the intervention of warm lemongrass compresse and warm cinnamon decoction compress on reducing the pain scale. [5]

The results of preliminary data collection at Panti Sudagaran, Banyumas Regency on September 11, 2019 , there were $32(45.71 \%)$ seniors experiencing osteoarthritis. In addition, the researcher also conducted physical assessments and interviews with 10 patients showing that there were $6(60 \%)$ patients whose joints hurt when moved on a scale of $5-6$ and $4(40 \%)$ experienced pain with a scale of 3 - 5 .

\section{RESEARCH METHOD}

This is is a quantitative research, a quasi-experimental design with two group pretest-post-test designs consisting of two treatments. Random sampling was used to collect data in this research. Respondents in this study were divided into 2, namely 15 respondents were applied with compress of boiled ginger for 20 minutes and 15 respondents were applied with compress of boiled cinnamon for 20 minutes. Using statistical tests with the "Mann Whitney" test, the research was conducted in January 2020 at Sudagaran Nursing Home.

\section{RESULT AND DISCUSSIONS}

Table 1. Respondent characteristics

\begin{tabular}{lcccc}
\hline $\begin{array}{c}\text { Respondent } \\
\text { characteristics }\end{array}$ & \multicolumn{2}{c}{$\begin{array}{c}\text { Ginger compress } \\
\text { intervention group }\end{array}$} & \multicolumn{2}{c}{$\begin{array}{c}\text { Cinnamon compress } \\
\text { intervention group }\end{array}$} \\
\cline { 2 - 5 } & Frequency & Percentage & Frequency & Percentage \\
\hline Age & 6 & $40 \%$ & 3 & \\
61 - 70 years old & 5 & $33,3 \%$ & 6 & $40 \%$ \\
71 - 80 years old & 4 & $26,7 \%$ & 6 & $40 \%$ \\
81 - 95 years old & & & & \\
Sex & 6 & $40 \%$ & 6 & $40 \%$ \\
Male & 9 & $60 \%$ & 9 & $60 \%$ \\
Female & & & & \\
Educational level & 7 & $46,7 \%$ & 7 & $20,7 \%$ \\
Primary School & 1 & $6,7 \%$ & 3 & $6,7 \%$ \\
First Secondary-school & 1 & $6,7 \%$ & 1 & $26,7 \%$ \\
Highschool & 6 & $40 \%$ & 4 & \\
Non-educated & & &
\end{tabular}

Based on the table above, most of the ginger compress intervention group was dominated by female respondents aged 61-70 years with education background of elementary school, while the cinnamon compress intervention group was dominated by female respondents aged 71-80 years with education background of elementary school.

Table 2. Pain before and after the application of ginger and cinnamon compress

\begin{tabular}{ccccc}
\hline \multirow{2}{*}{ Pain } & \multicolumn{2}{c}{ Ginger compress } & \multicolumn{2}{c}{ Cinnamon compress } \\
\cline { 2 - 5 } & Mean \pm SD & Range & Mean \pm SD & Range \\
\hline Before & $5,47 \pm 0,990$ & $4-7$ & $5,53 \pm 0,837$ & $4-7$ \\
After & $2,47 \pm 1,407$ & $0-5$ & $3,93 \pm 0,961$ & $2-6$ \\
\hline
\end{tabular}

Table 2 showed that the mean pain before ginger compress was 5.47 with a standard deviation of 0.990. The lowest level of pain before ginger compress was 4 and the highest was 7 . Meanwhile, after ginger compress application, the average reached 2.47 with the standard deviation of 1.407 . The lowest pain level is 0 and the highest is 5 . The average pain in the elderly before being given cinnamon compress was 5.53 with a standard deviation of 0.837 . The pain level in the elderly before being given a cinnamon compress was 4 at the lowest and the highest was 7. Meanwhile, after being given a cinnamon compress, an average of 3.93 was obtained with a standard deviation of 0.961 . The lowest pain level for the elderly was 2 and the highest was 6 . 
Tabel 3. The effectiveness of cinnamon and ginger compress

\begin{tabular}{ccc}
\hline Difference & $\begin{array}{c}\text { Effect size } \\
\text { (Grey dan Kinnear) }\end{array}$ & $\begin{array}{c}\text { Effect suze } \\
\text { (Kerby) }\end{array}$ \\
\hline $\begin{array}{c}\text { Before and after ginger } \\
\text { compress }\end{array}$ & 0,924 & 0,925 \\
$\begin{array}{c}\text { Before and after cinnamon } \\
\text { compress }\end{array}$ & 0,790 & 0,792 \\
\hline
\end{tabular}

The effectiveness of ginger compress shows effect sizes of 0.924 and 0.925 (large effect), the effectiveness of cinnamon compresses is 0.790 and 0.792 (large effect). According to Cohen the effect size is 0.10 (small effect), 0.30 (moderate effect), 0.50 (large effect).

\subsection{Respondent characteristics}

Based on these results, the occurrence of osteoarthritis is in line with increasing age. This is in accordance with the research which states that tolerance to pain increases with age, the more a person gets older, the understanding of pain and efforts to overcome it increases, where adults sometimes report pain if it is pathological and functionally damaged.

The results showed that most of the respondents were female. This is in accordance with research, which found that osteoarthritis was 10 times more common in women than men. This is estimated because at the age of 50-80 years women experience a significant decrease in estrogen hormone.

\subsection{Pain before and after the application of ginger and cinnamon compress}

The results showed that the level of pain decreased before and after the ginger compress intervention was applied. This makes the ginger compress can be used as therapy for the elderly who experience osteoarthritis pain. Ginger contains oleoresins such as zingeron, gingerol and shogaol. Oleoresin has strong anti-inflammatory and antioxidant potential. The non-volatile water and oil content in ginger functions as an enhancer that can increase the permeability of oleoresin to penetrate the skin without causing irritation or damage to the peripheral circulation. [6] Ginger compress reduces joint pain in the transduction stage, where at this stage ginger contains gingerol which contains cyclooxygenase which can inhibit the formation of prostaglandins as a pain mediator, resulting in a decrease in joint pain. So that ginger can be used as an alternative non-pharmacological treatment to reduce pain.

One of the benefits of ginger is to treat osteoarthritis because ginger contains the enzyme cyclooxygenase which can reduce inflammation in people with osteoarthritis. Besides that ginger also has a pharmacological effect, namely a hot and spicy feeling, which can relieve pain, stiffness, and muscle spasm or the occurrence of vasodilation in blood vessel . Giving ginger compresses in addition to relaxing muscles or body parts that are sore but also reduces pain intensity. [7] The mixture of warm water and grated fresh ginger will cause the hot effect of the warm water of the fresh and spicy ginger rhizome. The heat effect of ginger can cause vasodilation of blood vessels, resulting in increased blood circulation and decreased pain by eliminating inflammatory products such as bradykinin, histamine, and prostaglandins that cause pain. Heat will stimulate nerve cells to close so that the transmission of pain impulses to the spinal cord and brain can be inhibited. [8]

The heat effect of ginger can lead to vasodilation of blood vessels resulting in increased blood circulation and decreased pain by eliminating inflammatory products such as bradykinin, histamine, and prostaglandins that cause pain. Heat will stimulate nerve cells to close so that the transmission of pain impulses to the spinal cord from the brain can be inhibited. [9] The results of research show that out of a total of 20 respondents, the highest level of pain scale before the action was a scale of 8 , while the highest pain scale after action was a scale of 5. Overall the average pain scale reduction was 2.75. Measurement of the pain scale, obtained a low pain scale, namely 1 respondent $(5 \%)$, moderate pain to low pain was 12 respondents $(10 \%)$ and still 2 respondents (10\%), moderate pain was 3 respondents $(15 \%)$. From the results of statistical tests it can be concluded that there is an effect of warm compresses boiled ginger in elderly clients with knee osteoarthritis.

Research results show that descriptively before and after ginger compresses the number of respondents who complained of pain on a scale of 7-8 initially totaled 7 respondents, then decreased to 1 respondent, and the number of respondents who complained of pain was on a scale of 4-6 Initially 30 respondents then decreased to 24 respondents, and respondents who complained of pain on a scale of 1-3 initially 4 then increased to 16 respondents. This illustrates the success of ginger compresses in reducing the scale of osteoarthritis pain in the elderly. The results of study show that of a total of 42 respondents, there is a significant effect of giving warm compresses with ginger stew to reduce pain levels. [10] Research results show that of 57 respondents, the intensity of pain before being given a warm ginger compress had an average of 41.87 with a 
standard deviation of 12.053. While the pain intensity after being given a warm ginger compress had an average of 26.02 with a standard deviation of 10.865 . There is an influence on the pain intensity of the elderly before and after the warm ginger compress application.

The results of the study show that ginger compress therapy is more effective in reducing the scale of joint pain in the elderly compared to only using warm water compresses, it can be used as an easy and inexpensive alternative to joint pain management in the elderly. The result showed that the level of pain decreased before and after being given the cinnamon compress. This makes the cinnamon compress play a role in providing comfort for the elderly during osteoarthritis problem. The essential oil content in cinnamon can help in the absorption process into the skin and to see the benefits of cinnamon in reducing pain. The essential oil contained in cinnamon bark contains eugeno which has a very hot and spicy taste so it can open the pores in the skin. The addition of cinnamon in warm water further encourages the disposal of anti-inflammatory products that can improve blood circulation so that it can reduce pain.

The results of the study show that of a total of 15 respondents, the level of joint pain before being given a cinnamon compress, most of the respondents experienced moderate pain, namely 10 respondents $(67 \%)$ and mild pain as many as 5 respondents (33\%). The level of joint pain after being given a cinnamon compress, most of the respondents were at a mild pain level, namely 12 respondents (80\%) and moderate pain, namely 3 respondents $(20 \%)$. So it can be concluded that there is an effect of cinnamon compress on changes in the level of joint pain in the elderly. Research results show that of the 13 respondents the average pain scale before intervention was 6.92, with a mean difference of 2.07, a standard deviation of 0.954 with a minimum value of 5 and a maximum value of 8 . While on the pain scale after intervention obtained an average value of 4.85

\subsection{The effectiveness of cinnamon and ginger compress}

The effectiveness of ginger compresses is more effective than cinnamon compresses in reducing pain because ginger contains gingerol which contains cyclooxygenase which can inhibit the formation of prostaglandins as a pain mediator, resulting in decreased joint pain. So that ginger can be used as an alternative non-pharmacological treatment to reduce pain. Whereas in the cinnamon compress group was less effective due to the addition of cinnamon in warm water further encourages the disposal of anti-inflammatory products that can improve blood circulation so that it can reduce pain.

The content of fresh ginger rhizome and its active ingredient is oleoresin which consists of gingerol, songaol, and zingiberence which are homologs of phenol through a heating process. Heat degradation from gingerol to gingerone, shogaol, and other ingredients is formed by heating the fresh and dry rhizomes at a water solvent temperature of $100^{\circ} \mathrm{C}$. The components of ginger are able to suppress inflammation and are able to regulate biochemical processes that activate acute and chronic inflammation such as osteoarthritis by suppressing proinflammatory cytokines and chemokines produced by synoviocytes, chondrocytes, and leukocytes. Ginger can effectively inhibit chemokine expression. [11]

The addition of a mixture of cinnamon in warm compress therapy can further increase the reduction in pain, because cinnamon contains anti-inflammatory and anti-rheumatism which play a role in the healing process of joint inflammation that occurs in osteoarthritis. This is because cinnamon contains sinamaldehiod which can inhibit the inflammatory process so that it can overcome pain. The essential oil in cinnamon contains eugenol, where eugenol has a very hot and spicy taste so it can open the skin's pores. Cinnamon, which plays a role in inflammation, comes from cinnamaldehyde. The content of sinamaldehyde is able to enter the body systemic by the widening of the skin pores. Sinamaldehyde is thought to be able to inhibit lipoxygenase, which is a mediator in the body that is able to convert free arachidonic acid into leukotrienes, if the leukotrin is decreased, the inflammatory process will be inhibited and the pain complaints are reduced.

\section{CONSLUSION}

Based on the results of the study, it can be concluded that ginger compress is more effective than cinnamon compress in reducing pain with the effect size value of ginger compress of 0.29 (moderate effect) and cinnamon compress of 0.25 (moderate effect).

\section{REFERENCES}

[1] N. Dewi, W. Subawa dan A. Wiguna, "Hubungan status kesehatan berdasarkan WOMAC dengan kualitas hidup berdasarkan WHOQOL-BREF pada pasien osteoartritis lutut di Rumah Sakit Sanglah tahun 2016-2017," Intisari Sains Medis, vol. 9, no. 1, pp. 71-75, 2017.

[2] E. Asmaraningjati , R. Utami dan . A. Nusantoro, "Perbandingan Efektifitas Senam Tera dan Latihan Quadriceps Untuk Mengurangi Nyeri Pada Pasien Osteoartritis di Puskesmas Kartasura.," Jurnal Keperawatan, 2018. 
[3] R. Irza, "Hubungan Derajat Nyeri deengan Kelainan Radiologik Pada Lutut Pasien Osteoarthritis di RSUD Tagurejo,” 2015.

[4] J. Farizal, M. Leli dan Susiwati, "Kompres Jahe Merah Berpengaruh Terhadap Penurunan Skala Nyeri Osteoartritis Pada Lanjut Usia di Wilayah Kerja Puskesmas Kampung Delima Tahun 2016,” Jurnal Ilmu dan Teknologi Kesehatan, vol. 5, no. 2, p. 1, 2018.

[5] N. Yanti, Wiyadi dan H. Arifin, "Efektifitas Kompres Rebusan Serai Hangat dan Kayu Manis Hangat Terhadap Penurunan Skala Nyeri Rheumathoid Arthritis di Panti Sosial Tresna Werdha Nirwana Puri Samarinda," Jurnal Keperawatan, 2018.

[6] H. Masyhurrosyid, Kumboyon dan Y. Utami , "Pengaruh Kompres Hangat Rebusan Jahe Terhadap Nyeri Subakut dan Kronis pada Lanjut Usia dengan Osteoartritis Lutut di Puskesmas Arjuna Kecamatan Klojen Jawa Timur," Majalah Kesehatan FKUB, vol. 1, no. 1, 2016.

[7] Brunner dan Suddarth, "Topical Ginger Treatment With a Compress or Patch for Osteoarthritis Symptoms," Journal of Holistic Nursing American Holistic Nurses Association: New Zealand., vol. 1, no. 10, p. 20, 2012.

[8] Y. Podungge, "Pengaruh kompres jahe terhadap nyeri lutut pada lansia di wilayah kerja puskesmas Tamalate Kota Gorontalo,” Jurnal Universitas Negeri Gorontalo., 2015.

[9] . S. Niempoog , "The efficacy of powdered ginger in osteoarthritis of the knee. Pathumthani," Department of orthopaedic surgery thammasat university, 2012.

[10] P. Sherlyna, "Pengaruh pemberiankompres hangat rebusan parutan jahe terhadapnyeri pada lansia denganosteoartritis di pejeng kangin kabupaten gianyar," Jurnal Dunia Kesehatan, vol. 5, no. 2, 2016.

[11] Thomas, Simkin, A. Penny dan Ruth, Buku Saku Persalinan., Jakarta: EGC, 2015. 